\title{
Effect of Orthovanadate on Platelet Aggregation Induced by Platelet- Activating Factor
}

\author{
Aya Suenaga (née Yoshida) and Hiroshi Uekı* \\ Department of Biochemistry, Faculty of Pharmacy and Pharmaceutical Sciences, Fukuyama University; 1 Gakuen-cho, \\ Fukuyama, Hiroshima 729-0292, Japan. Received June 2, 2004; accepted August 9, 2004
}

\begin{abstract}
Orthovanadate (vanadate) inhibited the platelet aggregation induced by platelet-activating factor (PAF) in a dose-dependent manner. Propranolol, a nonspecific $\beta$-adrenergic receptor antagonist, and $\mathrm{H}-8$, a selective inhibitor of cAMP-dependent protein kinase (PKA), suppressed the inhibition of the PAF-induced platelet aggregation by vanadate. Vanadate increased the cAMP content in platelets accompanied by the activation of PKA. The $\beta$-adrenergic receptors of platelets have been reported to be abundant in the $\beta_{2}$ isoform, coupled to adenylyl cyclases (R. Kerry and M. C. Scrutton, Br. J. Pharmacol., 79, 681-691 (1983)). When the washed platelets were preincubated with vanadate, salbutamol, a selective $\beta_{2}$-adrenergic receptor agonist, or 8-Br-cAMP, the latter two mimicked the vanadate-induced anti-platelet aggregation and prolongation of clotting time of plasma, suggesting involvement of the increased intracellular cAMP content in both actions of vanadate. Butoxamine, a selective $\beta_{2}-$ adrenergic receptor antagonist, suppressed both actions of vanadate. The vanadate-induced increase in cAMP content was inhibited in part by butoxamine or genistein. These results suggest that vanadate inhibits the PAFinduced platelet aggregation by the stimulation of a cAMP/PKA-dependent process via the $\beta_{2}$-adrenergic receptor and receptor tyrosine kinases, and that the anti-platelet aggregation is involved in part in mechanisms of the anticoagulant action of vanadate.
\end{abstract}

Key words orthovanadate; platelet aggregation; genistein; cAMP; cAMP-dependent protein kinase; butoxamine

Vanadium was first discovered to be an inhibitor of $\mathrm{Na}^{+}$, $\mathrm{K}^{+}$-ATPase found in a commercial preparation of ATP from equine and rabbit skeletal muscle,$^{1)}$ and later recognized as a potent inhibitor of protein tyrosine phosphatase. ${ }^{2)}$ Orthovanadate (vanadate) mimics most biological effects of insulin on skeletal muscle and adipose tissue. These actions include the stimulation of glucose uptake, ${ }^{3)}$ the activation of glycogen synthase ${ }^{4)}$ the inhibition of lipolysis, ${ }^{5)}$ the stimulation of cAMP phosphodiesterase (PDE), ${ }^{6,7)}$ and an increase in lipoprotein lipase activity. ${ }^{8}$ A further interesting effect was reported by Heyliger et al. that oral administration of vanadate to streptozotocin-induced diabetic rats resulted in lowered blood glucose concentrations without a change in insulin concentrations. ${ }^{9)}$ In addition, vanadate has adrenergic actions such as a transient increase in the intracellular cAMP content accompanied by the activation of cAMP-dependent protein kinase (PKA). ${ }^{10,11)}$ Platelets play an important role in controlling blood loss through their adhesion to damaged blood vessels and the release of substances that act to further enhance aggregation. ${ }^{12,13)}$ Biochemical reactions involved in aggregation are initiated by the contact of agonists including ADP, collagen, thrombin, and platelet-activating factor (PAF) with receptors on the platelet membrane and amplified by the secretion of platelet granular substances through a release reaction. $^{14,15)}$ The activation status of the platelet is regulated through the intracellular $\mathrm{Ca}^{2+} / \mathrm{cAMP}$ concentration relationship, related secretion of dense granule ADP and ATP, and the balance between prostaglandin $I_{2}$ and thromboxane $A_{2}$, and the enzymatic system of kinases and phosphatases. ${ }^{14,16,17)}$ Treatment of cultured endothelial cells with PAF resulted in a marked decrease in $\beta$-adrenergic receptor density in the plasma membrane and depression of the isoproterenol-stimulated adenylyl cyclase activity. ${ }^{18)}$ The negative regulation of a cAMP-dependent process via $\beta$-adrenergic receptors may be involved in part in mechanisms of the cellular action of PAF. We previously reported that vanadate prolonged the clotting time of normal human plasma through mechanisms involving in part the inhibition of activity of both factor Xa and thrombin. ${ }^{19)}$ However, it is still unknown whether the effect of vanadate on platelet aggregation is involved in the anticoagulant action. Classically, peroxovanadate, a preparation of a combination of vanadate and $\mathrm{H}_{2} \mathrm{O}_{2}$, was reported to stimulate protein-tyrosine phosphorylation and aggregation of intact human platelets after entering cells. ${ }^{20,21)}$ In contrast, collagen-induced platelet aggregation was inhibited by vanadate, suggesting that phosphotyrosine phosphatase may be involved in platelet shape change and ATP release. ${ }^{22)}$ To resolve these discrepancies, further investigations on mechanisms of the vanadate action via a receptor signaling pathway are necessary.

This paper shows that vanadate inhibits the PAF-induced platelet aggregation by the stimulation of a cAMP/PKA-dependent process via $\beta_{2}$-adrenergic receptor, and that inhibition of the platelet aggregation is involved in part in the anticoagulant action of vanadate.

\section{MATERIALS AND METHODS}

Materials Vanadate $\left(\mathrm{Na}_{3} \mathrm{VO}_{4}\right)$, PAF, cephalin, apyrase, butoxamine, propranolol, salbutamol, H-8, genistein, and 8Br-cAMP were purchased from Sigma Chemical (St. Louis, MO, U.S.A.). cAMP enzyme immunoassay system was obtained from Amersham Pharmacia Biotech (Little Chalfont, England). PKA Assay Kit was purchased from Upstate Biotechnology (Lake Placid, NY, U.S.A.). All other chemicals used were of analytical grade. Blood was collected from male Japan white rabbits, weighing $3-4 \mathrm{~kg}$, purchased from Shimizu Laboratory Supplies (Kyoto, Japan).

Preparation of Platelet Suspensions Platelet-rich plasma was obtained from rabbit blood by centrifugation at $120 \mathrm{~g}$ for $20 \mathrm{~min}$ in the presence of a one-tenth volume of $3.8 \%$ sodium citrate solution. Platelet-poor plasma was sepa- 
rated from the platelet-rich plasma by centrifugation at $1400 \mathrm{~g}$ for $5 \mathrm{~min}$. Plasma-free platelets were prepared from the platelet-rich plasma by centrifugation at $800 \boldsymbol{g}$ for $15 \mathrm{~min}$, then washed twice with a modified Tyrode-Hepes buffer (137 mм NaCl, 2.7 mм KCl, $3.75 \mathrm{~mm} \mathrm{NaH}_{2} \mathrm{PO}_{4}, 1 \mathrm{~mm}$ $\mathrm{MgCl}_{2}, 3.8 \mathrm{~mm}$ Hepes, $\mathrm{pH}$ 6.7) supplemented with apyrase ( 3 units $/ \mathrm{ml}$ ), $5.6 \mathrm{~mm}$ glucose, and $0.35 \%$ bovine serum albumin. $^{21,23)}$ The washed platelets were resuspended in the buffer of $\mathrm{pH} 7.4$ and used throughout this study.

Platelet Aggregation Assays The washed platelets $\left(5 \times 10^{8}\right.$ cells $\left./ \mathrm{ml}\right)$ were preincubated with or without test samples at $37^{\circ} \mathrm{C}$ for $15 \mathrm{~min}$ in the buffer containing $1 \mathrm{mM} \mathrm{CaCl}_{2}$ and further incubated with $50 \mathrm{nM}$ PAF for up to $15 \mathrm{~min}^{24)}$ To monitor the platelet aggregation, a decrease in absorbance at $650 \mathrm{~nm}$ was measured using a microtiter-plate reader at $30-\mathrm{s}$ intervals after the addition of PAF. ${ }^{25}$ )

Measurement of Clotting Time Assays were carried out essentially according to the method of Funakoshi et al. ${ }^{19,26)}$ Briefly, the washed platelets $\left(3 \times 10^{8}\right.$ cells $\left./ \mathrm{ml}\right)$ were preincubated with or without test samples at $37^{\circ} \mathrm{C}$ for $15 \mathrm{~min}$, washed to remove test samples, diluted with the platelet-poor plasma, then incubated with kaolin $(50 \mathrm{mg} / \mathrm{ml})$ for $3 \mathrm{~min}$. Measurement of clotting time was started by the addition of cephalin/ $\mathrm{Ca}^{2+}$ to the reaction mixture.

Determination of cAMP Content The washed platelets $\left(10^{9}\right.$ cells $)$ were incubated with or without vanadate in $1 \mathrm{ml}$ of the buffer containing $1 \mathrm{~mm} \mathrm{CaCl}_{2}$ at $37^{\circ} \mathrm{C}$ for up to $10 \mathrm{~min}$. Incubated platelets were quickly frozen in dry ice-acetone and homogenized in $1 \mathrm{ml}$ of a chilled $6 \%$ trichloroacetic acid (TCA) for $30 \mathrm{~s}$ with a sonifier (Branson Sonifier Cell Disruptor 200, Branson Sonic Power, Tokyo). ${ }^{11)}$ The homogenate was centrifuged at $2500 \mathrm{~g}$ for $10 \mathrm{~min}$ to remove insoluble materials. After extraction of the TCA with water-saturated diethylether, the cAMP content of the residual solution was determined using a commercially available cAMP enzyme immunoassay system, according to the manufacturer's instructions (Amersham Pharmacia Biotech).

PKA Assays The washed platelets $\left(3 \times 10^{8}\right.$ cells $)$ were incubated with or without vanadate in $1 \mathrm{ml}$ of the buffer containing $1 \mathrm{~mm} \mathrm{CaCl}_{2}$ at $37^{\circ} \mathrm{C}$ for up to $60 \mathrm{~min}$. The incubated cells were homogenized with a microhomogenizer (NS310E, Nition Medical Science, Tokyo, Japan) in $1 \mathrm{ml}$ of chilled $10 \mathrm{~mm}$ Tris- $\mathrm{HCl}$ buffer, containing $250 \mathrm{~mm}$ sucrose, $10 \mathrm{~mm}$ sodium pyrophosphate, $1 \mathrm{~mm}$ benzamidine, and $0.1 \mathrm{~mm}$ $p$-amidino-phenylmethanesulfonyl fluoride. After removal of insoluble materials from the homogenate, residual solution was further centrifuged at $105000 \boldsymbol{g}$ for $60 \mathrm{~min}$ to separate the cytosolic fraction. ${ }^{27)}$ The PKA activity was determined using the PKA Assay Kit, according to the manufacturer's directions. Briefly, a mixture of the cytosolic fraction (5 $\mu \mathrm{g}$ protein), assay dilution buffer ( $\mathrm{pH} 7.2)$, cAMP, PKC/CaMK inhibitor cocktail, Mg/ATP, $\left[\gamma_{-}{ }^{32} \mathrm{P}\right] \mathrm{ATP}$, and kemptide as substrate was incubated at $30^{\circ} \mathrm{C}$ for $10 \mathrm{~min}$, in a volume of $60 \mu \mathrm{l}$. A $25 \mu \mathrm{l}$ aliquot of the reaction mixture was applied to phosphocellulose filter paper (Whatman p81) and washed repeatedly. Residual radioactivity on the filter paper was measured.

Statistical Analysis Results are expressed as the mean士 S.E. from four separate experiments, each performed in duplicate. The data were analyzed by unpaired Student's $t$-, Dunnet's, or Bonferroni tests.

\section{RESULTS AND DISCUSSION}

We initially investigated the induction of platelet aggregation by PAF. PAF stimulated the platelet aggregation up to $1 \mu \mathrm{M}$ in a dose-dependent manner (Fig. 1). Based on these results, assays of the platelet aggregation were started by the addition of $50 \mathrm{~nm}$ PAF to the reaction mixture. Vanadate inhibited the PAF-induced platelet aggregation in a range of $50-500 \mu \mathrm{M}$ concentrations (Fig. 2). The inhibition by 250 $\mu \mathrm{M}$ vanadate was suppressed by propranolol, a nonspecific $\beta$ adrenergic receptor antagonist, ${ }^{28)}$ or $\mathrm{H}-8$, a selective PKA inhibitor, ${ }^{29)}$ to various extents (Table 1 ). Vanadate induced an increase in cAMP content in platelets (Table 2). The maximal effect was observed at a 1-min incubation period. The PKA activity also was increased by vanadate in a time-dependent manner (Fig. 3). The maximal effect for a 30-min incubation period returned to the initial level after $60 \mathrm{~min}$. These results suggest that the activation of a cAMP/PKA-dependent process is involved in the vanadate action. The $\beta$ adrenergic receptors of platelets are characterized as mainly the $\beta_{2}$ isoform and coupled to adenylyl cyclases. ${ }^{30)}$ Therefore, whether salbutamol, a selective $\beta_{2}$-adrenergic receptor agonist, ${ }^{31)}$ and 8 -Br-cAMP mimic the vanadate actions was investigated, and both substances were found to inhibit the PAF-induced platelet aggregation as did vanadate (Table 3). The clotting time of the plasma containing the washed platelets preincubated with these also was prolonged. Butox-

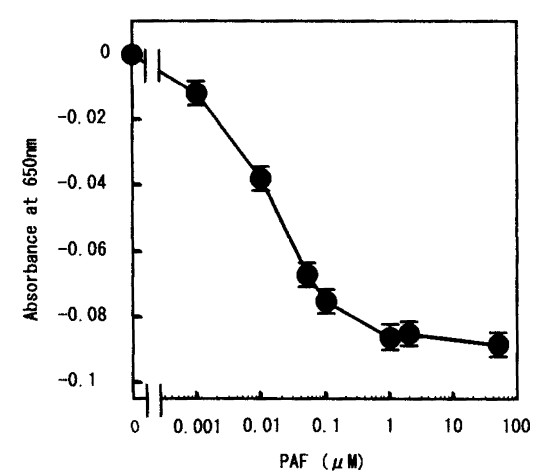

Fig. 1. Dose-Dependent Curve of PAF for Platelet Aggregation

The washed platelets $\left(3 \times 10^{8}\right.$ cells $\left./ \mathrm{ml}\right)$ were incubated with PAF in the indicated concentrations for up to $15 \mathrm{~min}$. Results were expressed as net decrease in absorbance at $650 \mathrm{~nm}$ from the control (without PAF).

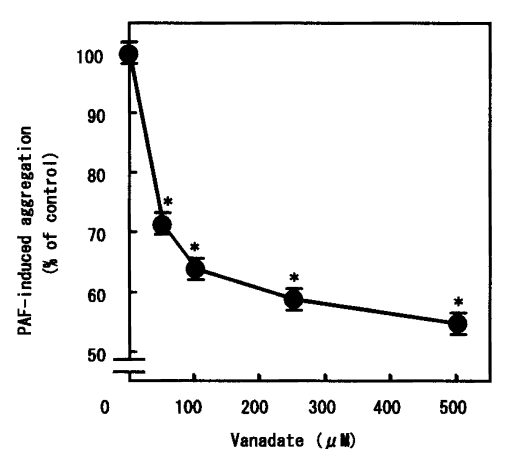

Fig. 2. Effect of Vanadate on PAF-Induced Platelet Aggregation

The washed platelets $\left(3 \times 10^{8}\right.$ cells $\left./ \mathrm{ml}\right)$ were incubated with vanadate at the indicated concentrations for $15 \mathrm{~min}$ and assayed for inhibition of PAF-induced platelet aggregation. Results are expressed as a percentage of the control (without vanadate). Significant differences compared with the control group: $* p<0.05$. 
Table 1. Effect of Propranolol or H-8 on Inhibition of PAF-Induced Platelet Aggregation by Vanadate

\begin{tabular}{cccc}
\hline \hline \multirow{2}{*}{ Inhibitor } & $(\mu \mathrm{M})$ & \multicolumn{2}{c}{ PAF-induced platelet aggregation (\%) } \\
\cline { 3 - 4 } & & Control & Vanadate \\
\hline \multirow{2}{*}{ Propranolol } & 0 & 100 & $50 \pm 4$ \\
& 10 & $98 \pm 4$ & $60 \pm 6$ \\
& 50 & $95 \pm 3$ & $65 \pm 3^{*}$ \\
H-8 & 100 & $93 \pm 5$ & $72 \pm 5^{*}$ \\
& 0 & 100 & $50 \pm 6$ \\
& 0.1 & $100 \pm 1$ & $75 \pm 5^{*}$ \\
& 1 & $97 \pm 2$ & $85 \pm 3^{*}$ \\
& 10 & $99 \pm 1$ & $88 \pm 2^{*}$
\end{tabular}

The washed platelets $\left(3 \times 10^{8}\right.$ cells $\left./ \mathrm{ml}\right)$ were preincubated with propranolol or $\mathrm{H}-8$ at the indicated concentrations for $15 \mathrm{~min}$ before a 15 -min incubation with or withou $250 \mu \mathrm{M}$ vanadate and assayed for the PAF-induced platelet aggregation. Results are expressed as a percentage of the control group without vanadate or inhibitor. Significant differences compared with each vanadate-treated group without inhibitor: $* p<0.05$.

Table 2. Effect of Vanadate on Intracellular cAMP Content

\begin{tabular}{ccc}
\hline \hline & \multicolumn{2}{c}{$\begin{array}{c}\text { Intracellular cAMP content } \\
(\mathrm{pmol} \text { cAMP/10 }\end{array}$} \\
Incubation time $(\mathrm{min})$ & Control & Vanadate \\
\cline { 2 - 3 } & $2.0 \pm 0.2$ & $2.0 \pm 0.3$ \\
Initial & $1.9 \pm 0.1$ & $3.8 \pm 0.4^{*}$ \\
1 & $2.1 \pm 0.1$ & $2.7 \pm 0.1^{*}$ \\
3 & $2.1 \pm 0.2$ & $2.2 \pm 0.3$ \\
\hline
\end{tabular}

The washed platelets $\left(10^{9}\right.$ cells $\left./ \mathrm{ml}\right)$ were incubated with or without $250 \mu \mathrm{M}$ vanadate for up to $10 \mathrm{~min}$ and assayed for intracellular cAMP content. Results are expressed in terms of pmol cAMP $/ 10^{8}$ platelets. Significant differences compared with the control at each time point: $* p<0.05$.

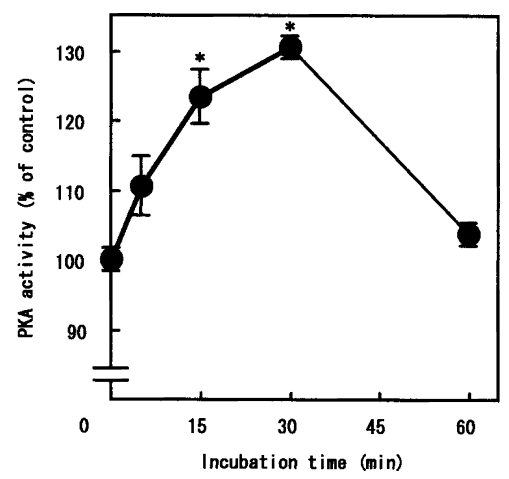

Fig. 3. Time Course of Effect of Vanadate on PKA Activity

The washed platelets $\left(3 \times 10^{8}\right.$ cells $\left./ \mathrm{ml}\right)$ were incubated with $250 \mu \mathrm{M}$ vanadate at the indicated concentrations and assayed for PKA activity. Results are expressed as a percentage of the control (without vanadate) at each time point. Significant differences compared with the initial: $* p<0.05$.

amine, a selective $\beta_{2}$-adrenergic receptor antagonist, ${ }^{32)}$ suppressed both actions of vanadate-induced anti-platelet aggregation and anticoagulant at concentrations of 50 and $100 \mu \mathrm{M}$ (Table 4). Atenolol and bupranolol, $\beta_{1^{-}}$and $\beta_{3}$-adrenergic receptor antagonists, respectively, ${ }^{33,34)}$ did not show any suppression of the anticoagulant action of vanadate (data not shown). The vanadate-induced increase in intracellular cAMP content was suppressed by butoxamine and genistein, an inhibitor of receptor tyrosine kinases of growth factors ${ }^{35}$ ) (Table 5). These results suggest that a cAMP-dependent process via the $\beta_{2}$-adrenergic receptor is involved in part in
Table 3. Effects of Vanadate, Salbutamol, or 8-Br-cAMP on PAF-Induced Platelet Aggregation and Clotting Time

\begin{tabular}{cccc}
\hline \hline Sample & $(\mu \mathrm{M})$ & $\begin{array}{c}\text { Aggregation } \\
(\% \text { of control })\end{array}$ & $\begin{array}{c}\text { Clotting time } \\
(\% \text { of control })\end{array}$ \\
\hline Vanadate & 0 & 100 & 100 \\
& 100 & $64 \pm 3^{*}$ & $135 \pm 6^{*}$ \\
& 250 & $58 \pm 2^{*}$ & $150 \pm 5^{*}$ \\
Salbutamol & 0 & 100 & 100 \\
& 0.1 & $61 \pm 5^{*}$ & $140 \pm 2^{*}$ \\
& 0.25 & $58 \pm 5^{*}$ & $144 \pm 2^{*}$ \\
8 -Br-cAMP & 0 & 100 & 100 \\
& 100 & $67 \pm 3^{*}$ & $135 \pm 6^{*}$ \\
& 1000 & $54 \pm 8^{*}$ & $144 \pm 7^{*}$
\end{tabular}

The washed platelets $\left(3 \times 10^{8}\right.$ cells $\left./ \mathrm{ml}\right)$ were incubated with vanadate, salbutamol, or 8-Br-cAMP at the indicated concentrations for $15 \mathrm{~min}$ and assayed for anti-platelet aggregation and anticoagulant actions. Results are expressed as a percentage of each control group (without test samples). Significant differences compared with each control group: $* p<0.05$.

Table 4. Effect of Butoxamine on Vanadate-Inhibited Platelet Aggregation and Vanadate-Prolonged Clotting Time

\begin{tabular}{ccc}
\hline \hline $\begin{array}{c}\text { Butoxamine } \\
(\mu \mathrm{M})\end{array}$ & $\begin{array}{c}\text { Vanadate-inhibited } \\
\text { aggregation }(\%)\end{array}$ & $\begin{array}{c}\text { Vanadate-prolonged } \\
\text { clotting time }(\%)\end{array}$ \\
0 & $55 \pm 5$ & $150 \pm 5$ \\
10 & $65 \pm 3$ & $145 \pm 5$ \\
50 & $83 \pm 5^{*}$ & $126 \pm 7^{*}$ \\
100 & $88 \pm 6^{*}$ & $118 \pm 1^{*}$
\end{tabular}

The washed platelets $\left(3 \times 10^{8}\right.$ cells $\left./ \mathrm{ml}\right)$ were preincubated with butoxamine at the indicated concentrations for $15 \mathrm{~min}$ before incubation with $250 \mu \mathrm{M}$ vanadate and assayed for the inhibition by vanadate of PAF-induced platelet aggregation and the vanadateprolonged clotting time. Results are expressed as a percentage of each control (without vanadate). Significant differences compared with the vanadate-treated group without butoxamine: $* p<0.05$.

Table 5. Effect of Butoxamine or Genistein on Vanadate-Induced Increase in Intracellular cAMP Content

\begin{tabular}{crcc}
\hline \hline & & \multicolumn{2}{c}{ Intracellular cAMP content $(\%)$} \\
\cline { 3 - 4 } Inhibitor & $(\mu \mathrm{M})$ & Control & Vanadate \\
\hline Butoxamine & 0 & 100 & $153 \pm 5$ \\
& 50 & $101 \pm 4$ & $123 \pm 5^{*}$ \\
Genistein & 0 & 100 & $158 \pm 7$ \\
& 40 & $105 \pm 2$ & $131 \pm 4^{*}$ \\
\hline
\end{tabular}

The washed platelets $\left(10^{9}\right.$ cells $\left./ \mathrm{ml}\right)$ were preincubated with butoxamine or genistein at the indicated concentrations for $15 \mathrm{~min}$ before a 1 -min incubation with or without $250 \mu \mathrm{M}$ vanadate and assayed for intracellular cAMP content. Results are expressed as a percentage of the control group without vanadate or inhibitors. Significant differences compared with each vanadate-treated group without inhibitor: $* p<0.05$.

the actions of vanadate. PAF, 5-hydroxytryptamine, or thrombin leads to platelet aggregation through activation of phospholipid-specific phospholipase C (PLC) and mitogen-activated protein kinase (MAPK) pathways. ${ }^{24)}$ The activated PLC stimulates a cleavage of inositol phospholipids to generate inositol-1,4,5-trisphosphate $\left(\mathrm{IP}_{3}\right)$ and diacylglycerol, which results in the mobilization of intracellular $\mathrm{Ca}^{2+}$ and the activation of protein kinase $\mathrm{C}$, respectively. PKA activated by an increase in intracellular cAMP content inhibits activation of $\beta_{2}$ isoform of PLC through phosphorylation of serine residues of the enzyme molecule. ${ }^{36)}$ Increased cAMP 
content also antagonizes the mobilization of intracellular $\mathrm{Ca}^{2+}$, probably due to inhibition of the flux in the polyphosphoinositide cycle. ${ }^{37,38)}$ Thus, the the function of some signaling molecules in platelets is regulated through cAMP/ PKA-dependent phosphorylation. We found that butoxamine or genistein partially inhibits the vanadate-induced increase in cAMP content in platelets. The adenylyl cyclase system is a membrane-associated complex of receptors, $G$ proteins, and enzyme that is activated or inhibited in response to effectors. G proteins are activated when they bind GTP and are inactivated by hydrolysis of the nucleotide to GDP. The stimulation of adenylyl cyclase activities of adipocytes and liver plasma membranes by vanadate was inhibited by an excess of GTP or non-hydrolyzable GTP-analogs, 5' -guanylylimidodiphosphate and guanylyl $5^{\prime}-[\gamma$ thio $]$-triphosphate. ${ }^{39)}$ The effect of vanadate was thought to be due to the formation of a GDP- $\mathrm{VO}_{4}^{3-}$ complex. Therefore, vanadate may exert its action through the activation of $\mathrm{G}$ proteins. On the other hand, vanadate stimulates a tyrosine kinase-dependent enhancement of adenylyl cyclase function in human and rat aortic vascular smooth muscle cells, human lymphocytes, and human aortic endothelial cells. ${ }^{40}$ The activation of adenylyl cyclase isoform 6 expressed in HEK 293 cells also is mediated by the receptor tyrosine kinase activation with growth factors and vanadate. ${ }^{41)}$ In response to vanadate, an increase in serine, but not tyrosine, phosphorylation of adenylyl cyclase isoform 6 was observed. The increased serine phosphorylation was suggested to be due to the activation of a serine/threonine kinase, raf-1 kinase, sensitive to receptor tyrosine kinase. Thus, the tyrosine kinase-mediated pathway also may be seen as a regulator of adenylyl cyclase function. Human platelets contain platelet-derived growth factor (PDGF) in their $\alpha$-granules and have functionally active PDGF $\alpha$-receptors which were identified as a $170-\mathrm{kDa}$ glycosylated protein tyrosine kinase. ${ }^{42)}$ Preincubation of platelets with PDGF inhibited thrombin-induced platelet aggregation, suggesting that the PDGF $\alpha$-receptor tyrosine kinase takes part in a negative feedback regulation during platelet activation. PDGF stimulated cAMP synthesis in cultured airway smooth muscle cells. ${ }^{43}$ Vanadate resulted in the increased phosphorylation of PDGF receptor in the osteoblast-like cells although the effect was lesser than PDGF. ${ }^{44)}$ The PDGF $\alpha$-receptor tyrosine kinase may be one of the target enzymes of vanadate. Vanadate seems to exert the activation of adenylyl cyclase via dual signaling pathways of the $\beta$-adrenergic receptors and receptor tyrosine kinases of growth factors including PDGF. The PAF-induced platelet aggregation is inhibited by wortmannin, a potent inhibitor of phophatidylinositol 3-kinase (PI3K), ${ }^{45}$ ) or PD98059, a specific inhibitor of MAPK kinase, ${ }^{46)}$ suggesting involvement of the MAPK activation via $\mathrm{PI} 3 \mathrm{~K}$ in the action of PAF. ${ }^{24,47)}$ MAPKs, a group of kinases responsive to a variety of environmental stimuli, are divided into three subfamilies of the p42/p44 MAPKs, c-Jun NH2-terminal kinase/stress-activated protein kinases, and p38 MAPKs. ${ }^{48)}$ These enzymes are activated by their upstream kinases and downregulated by phosphatases. Each of the subfamilies appears to have its own set of activators, although there is a certain amount of crossover in the pathway. In hepatocytes, vanadate resulted in the increased phosphorylation and activation of $\mathrm{p} 44 \mathrm{MAPK}{ }^{27)}$ The activation was dependent on the PKA activation and independent of a PI3K- dependent process. Although two forms of MAPKs, p42 and p44 proteins, have been identified in platelets, the increased phosphorylation and activation of $\mathrm{p} 42$ MAPK alone were observed with the aggregation induced by thrombin, involving a stimulated phosphorylation pathway similar to that by PAF. ${ }^{24,49)}$ Thus, the activation of $\mathrm{p} 42$ MAPK but not $\mathrm{p} 44$ MAPK appears to be involved in the induction of platelet aggregation. This may be the reason why the vanadate-induced MAPK activation is independent of the platelet aggregation.

In conclusion, the results of this investigation indicate that vanadate inhibits the PAF-induced platelet aggregation through the activation of a cAMP/PKA-dependent process, and that inhibition of the platelet aggregation is involved in part in the anticoagulant action of vanadate.

\section{REFERENCES}

1) Cantley L. C., Jr., Josephson L., Waener R., Yanagisawa M., Lechene C., Guidotti G., J. Biol. Chem., 252, 7421 -7423 (1977).

2) Swarup G., Speeg K. V., Jr., Cohen S., Garbers D. L., J. Biol. Chem., 257, 7298-7301 (1982).

3) Shisheva A., Shechter Y., Biochemistry, 31, 8059-8063 (1992).

4) Tamura S., Brown T. A., Whipple J. H., Fujita-Yamaguchi Y., Dubler R. E., Cheng K., Larner J., J. Biol. Chem., 259, 6650-6658 (1984).

5) Duckworth W. C., Solomon S. S., Liepnieks J., Hamel F. G., Hand S., Peavy D. E., Endocrinology, 122, 2285-2289 (1988).

6) Ueki H., Okuhama R., Sera M., Inoue T., Tominaga N., Morita T., Endocrinology, 131, 441-446 (1992).

7) Ueki H., Mitsugi S., Kawashima Y., Motoyashiki T., Morita T., Endocrinology, 138, 2784-2789 (1997).

8) Sera M., Tanaka K., Morita T., Ueki H., Arch. Biochem. Biophys., 279, 291-297 (1990)

9) Heyliger C. E., Tahiliani A. G., McNeil J. H., Science, 227, 1474 1476 (1985).

10) Morita T., Sakata K., Kanagawa A., Ueki H., Biol. Pharm. Bull., 17, 577-580 (1994).

11) Motoyashiki T., Morita T., Ueki H., Biol. Pharm. Bull., 19, 1412 1416 (1996).

12) Davie E. W., Fujikawa K., Annu. Rev. Biochem., 44, 799-829 (1975).

13) Siess W., Physiol. Rev., 69, 58-78 (1989).

14) Vizcaino-Salazar G., Invest. Clin., 35, 41-62 (1994).

15) Porta C., Maiolo A., Tua A., Grignani G., Haematologia, 85, 820825 (2000).

16) Soslau G., Youngprapakorn D., Biochim. Biophys. Acta, 1355, 131140 (1997).

17) Lages B., Weiss H. J., Thromb. Haemost., 81, 286-292 (1999)

18) Grigorian G. Y., Mirzapoyazova T. Y., Resink T. J., Danilov S. M., Tkachuk V. A., J. Mol. Cell Cardiol., 21 (Suppl. 1), 119-123 (1989).

19) Funakoshi T., Shimada H., Kojima S., Kubota Y., Morita T., Tominaga N., Ueki H., Chem. Pharm. Bull., 40, 174-176 (1992).

20) Inazu T., Taniguchi T., Yanagi S., Yamamura H., Biochem. Biophys. Res. Commun., 170, 259-263 (1990).

21) Blake R. A., Walker T. R., Watson S. P., Biochem. J., 290, 471-475 (1993).

22) Chiang T. M., Thromb. Res., 67, 345-354 (1992).

23) Akiba S., Murata T., Kitatani K., Sato T., Biol. Pharm. Bull., 23, 1293-1297 (2000).

24) Shah B. H., Rasheed H., Rahman I. H., Shariff A. H., Khan F. L., Rahman H. B., Hanif S., Saeed S. A., Exp. Mol. Med., 33, 226-233 (2001).

25) Horn F., Coutinho dos Santos P., Termignoni C., Arch. Biochem. Biophys., 384, 68-73 (2000).

26) Funakoshi T., Heimark R. L., Hendrickson L. E., McMullen B. A., Fujikawa K., Biochemistry, 26, 5572-5578 (1987).

27) Watanabe T., Satoh H., Kohara K., Takami R., Motoyashiki T., Morita T., Ueki H., Biol. Pharm. Bull., 27, 789-796 (2004).

28) Barrett A. M., Cullun V. A., Br. J. Pharmacol., 34, 43-55 (1968).

29) Hidaka H., Kobayashi R., Annu. Rev. Pharmacol. Toxicol., 32, $377-$ 397 (1992).

30) Kerry R., Scrutton M. C., Br. J. Pharmacol., 79, 681-691 (1983). 
31) Freyss-Beguin M., Griffaton G., Lechat P., Picken D., Quennedey M. C., Rouot B., Schwartz J., Br. J. Pharmacol., 78, 717-723 (1983).

32) Wasserman M. A., Lew B., J. Pharmacol. Exp. Ther., 182, 256- 263 (1972).

33) Eriksson J. W., Jansson P. A., Foley K., Lithell H., J. Hypertens., 14, 1469-1475 (1996).

34) Koike K., Takayanagi I., Ichino T., Koshikawa H., Nagatomo T., Eur. J. Pharmacol., 334, 217-221 (1997).

35) Akiyama T., Ishida J., Nakagawa S., Ogawara H., Watanabe S., Itoh N., Shibuya M., Fukami Y., J. Biol. Chem., 262, 5592-5595 (1987).

36) Liu M., Simon M. I., Nature (London), 382, 83-87 (1996).

37) Zavoico G. B., Feinstein M. B., Biochem. Biophys. Res. Commun., 120, 579-585 (1984).

38) Ryningen A., Jensen B. O., Holmsen H., Biochim. Biophys. Acta, 1394, 234-248 (1998).

39) Combest W. L., Johnson R. A., Arch. Biochem. Biophys., 225, 916927 (1983).

40) Tan C. M., Macdonald C. J., Chorazyczewski J., Burry A. F., Feldman
R. D., Clin. Pharmacol. Ther, 66, 275-281 (1999).

41) Tan C. M., Kelvin D. J., Lichfield D. W., Ferguson S. S. G., Feldman R. D., Biochemistry, 40, 1702-1709 (2001).

42) Vassbotn F. S., Havnen O. K., Heldin C. H., Holmsen H., J. Biol. Chem., 269, 13874-13879 (1994).

43) Pyne N. J., Pyne S., Cell Signal., 10, 363-369 (1998).

44) Davidai G., Lee A., Schvartz I., Hazum E., Am. J. Physiol., 263 (2 Pt 1), E205-209 (1992).

45) Okada T., Sakuma I., Fukui Y., Hazeki O., Ui M., J. Biol. Chem., 269, 3563-3567 (1994).

46) Pang L., Sawada T., Decker S. J., Saltiel A. R., J. Biol. Chem., 270, 13585-13588 (1995).

47) Lauener R. W., Stevens C. M., Sayed M. R., Salari H., Duronio V., Biochim. Biophys. Acta, 1452, 197-208 (1999).

48) Lee C. M., Onesim D., Reddy C. D., Dhanasekaran N., Reddy E. P., Proc. Natl. Acad. Sci. U.S.A., 99, 14189-14194 (2002).

49) Papkoff J., Chen R. H., Blenis J., Forsman J., Mol. Cell Biol., 14, $463-472$ (1994). 